\section{REVIEW ARTICLE}

\title{
The biosynthesis of periplasmic electron transport proteins in methylotrophic bacteria
}

\author{
Pat M. Goodwint and Christopher Anthony \\ Author for correspondence: Chris Anthony. Tel: +44 1703 594280. Fax: +44 1703594459. \\ e-mail: C.Anthony@Soton.ac.uk
}

Department of Biochemistry, University of Southampton, Southampton SO16 7PX, UK

Keywords: periplasm, methylotrophs, protein processing, quinoproteins, cytochromes

\section{Electron transport in methylotrophs}

Methylotrophic bacteria are characterized by their ability to grow on reduced $\mathrm{C}_{1}$ compounds such as methane, methanol or methylamine and on related compounds such as dimethylamine and trimethylamine (Anthony, 1982). When Gram-negative methylotrophs grow on $C_{1}$ compounds a high proportion of their energy metabolism occurs in the periplasm, a feature they share with the chemolithotrophs (Anthony, 1986, 1992). This contrasts with the situation in typical aerobic, heterotrophic bacteria, in which most dehydrogenases (and therefore most energy metabolism) occur in the cytoplasm or cytoplasmic membrane. These dehydrogenases are usually either $\mathrm{NAD}^{+}$-linked or flavoproteins, and are coupled to an electron transport system involving ubiquinone and cytochrome $b$; the only periplasmic component is usually a small cytochrome $c$ similar to that found in the intermembrane space of mitochondria. The unusual site of energy metabolism in methylotrophs is reflected in the high concentrations of their periplasmic electron transport proteins; in Metbylobacterium extorquens, for example, the concentrations of the proteins involved specifically in methanol oxidation are about $0.5 \mathrm{mM}$ (Beardmore-Gray et al., 1983; Anthony, 1986). Methylotrophs growing on methanol or methylamine therefore provide a valuable system for investigating the biosynthesis of periplasmic proteins. Some of the processes involved are, of course, similar to those necessary for the synthesis of any protein that is not cytoplasmic; in addition, for electron transport proteins it is necessary to provide their redox active prosthetic groups. The development of methods for studying the genetics of methylotrophs (especially the Metbylobacterium species and Paracoccus denitrificans), together with the recent elucidation of the structure of the unusual dehydrogenases involved in oxidation of methanol and methylamine, makes it an appropriate time to review this field.
This review will concentrate on the biosynthesis of electron transport proteins involved specifically in the aerobic oxidation of methanol and methylamine by way of quinoproteins. These are methanol dehydrogenase and its primary electron acceptor, cytochrome $c_{L}$; and methylamine dehydrogenase and its primary electron acceptor, which is normally amicyanin, a blue copper protein. These are all soluble, periplasmic proteins and electrons are usually transferred from the primary electron acceptors to typical membrane-bound terminal oxidases by way of a Class I $c$-type cytochrome (Fig. 1) (Anthony, 1992, 1993a). When methylotrophs are growing anaerobically in the presence of nitrate additional

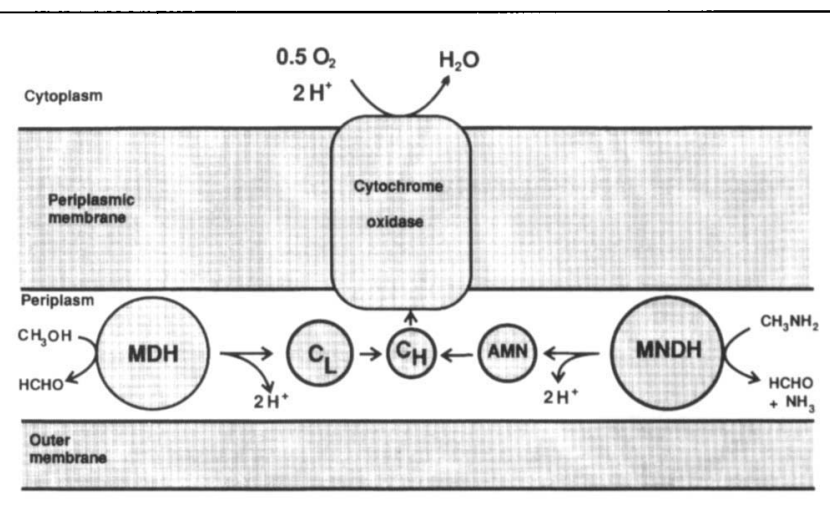

Fig. 1. The periplasmic 'methanol oxidase' and 'methylamine oxidase' electron transport systems in methylotrophs. The quinoprotein dehydrogenases pass on electrons one at a time to the electron acceptors, liberating protons into the periplasm. The oxidase is cytochrome $a_{3}$ or cytochrome co. The dimensions of the periplasm, the periplasmic membrane and the proteins are approximately to scale. $M D H$, methanol dehydrogenase; $M N D H$, methylamine dehydrogenase; $C_{L}$, cytochrome $C_{L}$ (cytochrome $C_{5511}$ in $P$. denitrificans); $C_{H}$ (cytochrome $C_{550}$ in $P$. denitrificans), a typical small Class I c-type cytochrome (this may be replaced by a blue copper protein like azurin in some bacteria); AMN, blue copper protein, amicyanin (this may be replaced in $M$. methylotrophus by Mauo, a c-type cytochrome). For reviews of the variety of electron transport chains in methylotrophs see Anthony (1992, 1993a). 
periplasmic electron transport proteins are induced (Ferguson, 1988; Anthony, 1993a).

The events which occur during the biosynthesis of a periplasmic electron transport protein are summarized as follows, although after the first step (gene expression) the sequence is not necessarily in the order presented here.

(a) Expression of structural genes, genes required for synthesis of the prosthetic group, and genes encoding proteins involved in processing. The initial product of expression of a gene encoding a periplasmic protein is a preprotein with an $\mathrm{N}$-terminal signal peptide.

(b) Transport of the unfolded preprotein across the membrane by a translocase system, directed by the signal peptide.

(c) Cleavage of the signal peptide from the preprotein.

(d) Folding of the protein, including proline isomerization reactions, the formation of the correct disulphide bridges and incorporation of metal ions essential for structure or for redox activity.

(e) Syntbesis of prosthetic groups and their transport to the periplasm.

(f) Insertion of prosthetic groups or modification of residues on the protein to produce a redox active prosthetic group.

(g) Assembly of the subunits to form the mature protein.

The next section outlines the pathways involved in the transport of proteins into the periplasm in bacteria. This process has not been studied in methylotrophs but the mechanisms for translocation of most of their periplasmic proteins are likely to be similar to those operating in Eschericbia coli. Specific aspects of the biosynthesis of the methanol and methylamine oxidation systems are then described in the next two sections.

\section{Translocation of proteins into the periplasm}

Detailed bibliographies on this topic are provided in a number of recent reviews (Wickner et al., 1991; Hardy \& Randall, 1993; Oliver, 1993; Pugsley, 1993; Wolin, 1994).

\section{Signal peptides}

As indicated above, proteins destined for export are recognized by the presence of an $\mathrm{N}$-terminal signal peptide (Fig. 2), which is cleaved by a signal peptidase during or immediately after translocation. Typical signal peptides are 16-26 residues long and have the following features: a basic $\mathrm{N}$-terminal region; a central hydrophobic sequence able to form an $\alpha$ helix; a non-helical C-terminal domain with a helix-disrupting residue (usually glycine or proline) at -6 ; and small side-chain residues at -3 and -1 (often alanine). This is the recognition site for signal peptidase I, which is responsible for removing the signal peptide from the preprotein after translocation.

The positively charged $\mathrm{N}$-terminus of the signal peptide can react with negatively charged phospholipid head- groups in the membrane. Model studies indicate that the central apolar region can span the membrane as an $\alpha$ helix or $\beta$ sheet, and that its interaction with the membrane could initiate protein export. However, it is not obvious how the sequences beyond the C-terminal of the signal peptide, which are generally hydrophilic, would get pulled into and across the membrane. It has been suggested that it is more likely that the signal peptide is required for interaction of the preprotein with specific 'pilot proteins' [SecB or a signal recognition particle (SRP); see below].

There are two other types of signal sequence, but these are less common. The 'lipoprotein signal peptide' is shorter than the standard sequence, contains a more hydrophobic central region and has a cysteine residue immediately after the cleavage site. It is cleaved by signal peptidase II. The third type, cleaved by type IV prepilin peptidase, is rare and has a highly conserved cleavage site (Q.R/K.G.F/M) between the $\mathrm{N}$-terminal region and the central hydrophobic region.

\section{Targeting of preproteins to the cytoplasmic membrane}

In E. coli there are two ways in which preproteins can be targeted to the cytoplasmic membrane. There is probably considerable functional redundancy between these two pathways, although it is likely that any given protein will normally use only one of them.

The first pathway involves $\operatorname{Sec} A$ and $\operatorname{SecB}$, which are components of the general secretory (Sec) pathway (Pugsley, 1993). SecB is a molecular chaperone which binds to the preprotein during and/or after translation, preventing it from aggregating or folding into a stable state in the cytoplasm, and thus maintaining it in a conformation compatible with export. SecB probably does not recognize the signal peptide directly; instead it is thought that possession of this sequence slows down folding of the preprotein and enables the chaperone to bind to multiple sites on the nascent polypeptide. The SecB-preprotein complex then interacts with a peripheral membrane protein, SecA. This is a dimer with ATPase activity which can bind to preproteins and target them to the translocation apparatus in the membrane.

The second pathway, which is very similar to that by which eukaryotic proteins are targeted to the endoplasmic reticulum, has only recently been described in $E$. coli (Wolin, 1994). The eukaryotic pathway involves a cytoplasmic ribonucleoprotein SRP, its membrane-bound receptor, and GTP or ATP. The SRP is a complex rodshaped particle consisting of six polypeptides and an RNA molecule of 300 nucleotides, which recognizes and binds signal sequences on nascent polypeptides. It targets the complex of ribosome plus nascent preprotein to the SRP receptor in the membrane. The complex is then transferred to the translocation apparatus and the SRP is released in a reaction requiring GTP hydrolysis. A ribonucleoprotein particle resembling SRP, together with a protein homologous to its receptor, have now been identified in E. coli; SecA is also probably necessary for 


MxaF (MDH $\alpha$ subunit)
MxaG (cytochrome $c_{\mathrm{L}}$ )
MxaJ
MxaI
MauA (MNDH $\beta$ subunit)
MauB (MNDH $\alpha$ subunit)
MauC (amicyanin)
MauL
Maug (peroxidase ?)
MauM
Maud

MSRFVTSVSALAMLALAPAALSSGAYA
MMNRVRIGTALLGLTLAGIALPALA
MSLVNGRRRTAASVVALTAALTALA
MLTTLIAAAIVALSGLAAPALA
MLGKSQFDDLFEKMSRKVAGHTSRRGF IGRGTAVAGVALVPLLPVDRRGRVSRANA
MMTHAYTKVRQALCWGSATLGAAALA
MRALAFAAALAAFSATAALA
MVMNTMLRVLTVSLAFALTSYALPAAA
MRAILP IPVLIAWAMVVCGGAYA
MAKPKSP SRRELLTNGVRAAGVTCLAGLALTAYVESASRAEA
MTMQFLIASNVLLWLALIG

Fig. 2. Signal sequences of the $M x a$ and Mau preproteins of $M$. extorquens. Positively charged residues are in bold script; at the $\mathrm{N}$-termini these may interact with the phospholipids of the periplasmic membrane. The peptidase recognition sites at the C-termini of the signal peptides are underlined. The signal peptides for the Mxa preproteins were taken from Nunn \& Anthony (1988), Nunn et al. (1989) and Anderson et al. (1990). Those for the Mau preproteins were from Chistoserdov \& Lidstrom (1991) and Chistoserdov et al. (1994a). Most of these signal peptides are typical of periplasmic preproteins; exceptions are those on the methylamine dehydrogenase $\beta$ subunit (MauA) and the MauD preprotein; this has a typical lipoprotein signal peptide but it is almost certainly a periplasmic protein (Chistoserdov et al., 1994a). MDH, methanol dehydrogenase; MNDH, methylamine dehydrogenase.

interaction with the translocation apparatus in this pathway.

In addition to the two pathways outlined here, it should be noted that there is some evidence for translocation mechanisms that are independent of signal peptides, Sec proteins and SRPs (Salmond \& Reeves, 1993; Brandner \& Donohue, 1994); because the precursors of the periplasmic proteins described in methylotrophic bacteria all have signal peptides, these mechanisms will not be further discussed.

\section{The translocation apparatus}

Once the preprotein has been targeted to the membrane it can interact with the integral membrane components of the translocation channel formed by SecE and SecY; a third protein (called band 1) is also thought to be involved. Translocation requires both ATP (for activity of SecA) and a protonmotive force. Two other proteins - SecD and $\mathrm{SecF}$-are probably needed at a late stage in translocation and it has been suggested that they catalyse release of the polypeptide from the translocase and/or folding of the polypeptide on the face of the periplasmic side of the membrane. There are considerable structural and functional similarities between the translocation apparatus in prokaryotes and eukaryotes, indicating that it has been conserved during evolution.

\section{Cleavage of the signal peptide}

Following translocation the signal peptide is removed by one of the three specific membrane-bound signal peptidases mentioned earlier. Most preproteins destined for the periplasm have standard signal peptides and are cleaved by signal peptidase I (LepB), which has its active site in the periplasm. This does not belong to any of the four major classes of proteases and is thought to have a novel mechanism of catalysis, similar to that of the $\beta$ lactamases, whereby a carboxylate acts as the general base (Dalbey \& von Heijne, 1992). The protein is released into the periplasm and the signal peptide is probably hydrolysed by a specific cytoplasmic peptidase (Novak $e t$ al., 1986).

\section{Folding of the periplasmic protein}

The preprotein crosses the membrane in the unfolded state and it might be expected that, on its release into the periplasm, molecular chaperones would be required to prevent unwanted folding pathways. However, at present there is little evidence for periplasmic, broad specificity chaperones equivalent to the cytoplasmic GroE (Wulfing \& Pluckthun, 1994).

At least two of the steps in protein folding require catalytic activity, namely cis-trans prolyl isomerization and disulphide bond formation, the latter being common in periplasmic proteins but not in cytoplasmic proteins. There is good evidence that the periplasm of $E$. coli contains both prolyl isomerase (Liu \& Walsh, 1990) and disulphide isomerase (for reviews see Bardwell \& Beckwith, 1993; Bardwell, 1994; Loferer \& Hennecke, 1994). The disulphide isomerase is a member of the thioredoxin superfamily and contains a very reactive disulphide bond which readily oxidizes free thiols, becoming reduced in the process. It is reoxidized by an integral membrane protein, DsbB. A third periplasmic thioredoxin-like protein, DsbC, is thought to enhance DsbA activity and may be particularly important in internal rearrangement (isomerization) reactions (Bardwell \& Beckwith, 1993; Bardwell, 1994). 
<smiles></smiles>

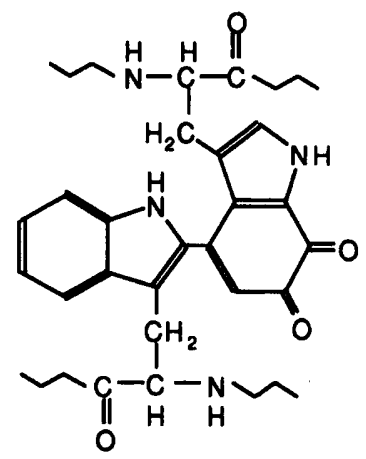

$P Q Q$
(1)
M. extorquens AMI
M. organophilum XX
P. denitrificans

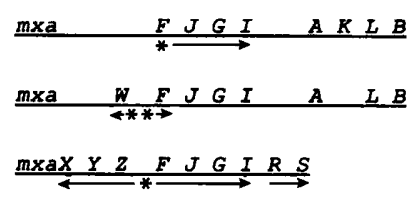

(2) The mxb and pqq gene cluster
M. extorguens AM1
M. organophilum XX
M. organophilum DSM

PQqA BCGD MXb M (N D A ) DgqA $\quad G \quad \operatorname{mxb}(M \quad N D)$

DQqA BCGDE

(3) The axc gene cluster
M. extorquens AM1
M. organophilum $\mathrm{XX}$
$\operatorname{m\times c}(A) \quad E)$
$\frac{m \times c(0 \cup E)}{*}$

(4) The med gene cluster

M. extorquens AM1 $\underline{m \times d(R S)}$

(5) The pqqar gene cluster
M. extorquens AMI
M. organophilum DSM
DQqE $F$
pqq $F$

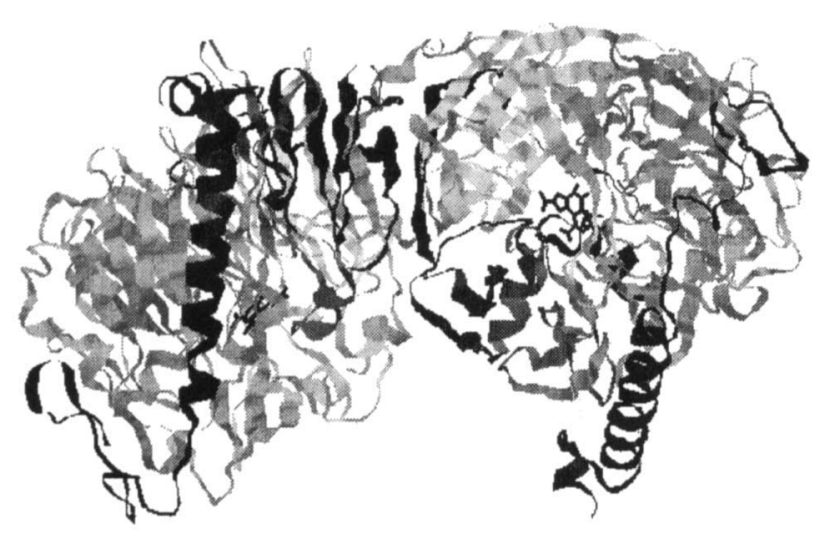

Fig. 4. The structure of the $\alpha_{2} \beta_{2}$ tetramer of methanol dehydrogenase. An indication of the radial symmetry in the $\alpha$ subunit is seen on the right-hand side of the tetrameric structure; the PQQ is seen near the centre of symmetry and the (darker) helical $\beta$ subunit is wrapped around the outside of the $\alpha$ subunits.

\section{Synthesis of the methanol oxidation system}

Methanol is oxidized to formaldehyde by methanol dehydrogenase, a quinoprotein which has pyrroloquinoline quinone (PQQ, Fig. 3) as its prosthetic group (for reviews see Anthony, 1986, 1993b). The enzyme is an $\alpha_{2} \beta_{2}$ tetramer and its three-dimensional structure has recently been elucidated (Fig. 4) (Xia et al., 1992; Blake et al., 1994; White et al., 1993; Anthony et al., 1994; Ghosh et al., 1995). Each $\alpha$ subunit (66 kDa in $M$. extorquens AM1) contains one molecule of PQQ and one $\mathrm{Ca}^{2+}$ at its active site, and has two disulphide bonds. One of these is a novel type of bridge between adjacent cysteine residues; the bond itself is non-planar and the resulting structure is a novel eight-membered ring in

\begin{abstract}
Fig. 5. Organization of mox genes in $M$. extorquens, $M$. organophilum and $P$. denitrificans. This figure shows the organization of the gene clusters, but is not drawn to scale. * An asterisk indicates methanol regulated promoters. Arrows indicate the direction of transcription when known. The order of genes written in parentheses is not known. Data are taken from Harms et al. (1993), Xu et al. (1993), Lidstrom et al. (1994) and Morris et al. (1994).
\end{abstract}

contact with the plane of the PQQ in the active site. An intermediate during the reaction cycle is the free radical semiquinone form of $\mathrm{PQQ}$ and the function of the disulphide ring may be to protect this unstable form (Anthony et al., 1994). Each $\alpha$ subunit has three cis peptide bonds stabilized by the rings of proline side chains, which will require the activity of a prolyl isomerase for their formation. The main chain of the $\alpha$ subunit is arranged in an unusual 'propeller' fold consisting of a series of eight radially arranged $\beta$-sheets held together by specific 'docking' motifs to form a superbarrel which encloses the PQQ. The $\beta$ subunits ( $8.5 \mathrm{kDa}$ in $M$. extorquens AM1) are not separate globular subunits but are wrapped around the $\alpha$ subunits in a novel extended configuration (Fig. 4); each has a single disulphide bridge.

The primary electron acceptor of methanol dehydrogenase is an unusual cytochrome, known as cytochrome $c_{\mathrm{L}}$ (cytochrome $c_{551 \mathrm{i}}$ in $P$. denitrificans) (Anthony, 1992). The cytochrome from $M$. extorquens AM1 is about $19 \mathrm{kDa}$ in size and, apart from its typical haem-binding site (CysSer-Gly-Cys-His), its sequence has little homology with any other proteins. In particular the conserved features of other $c$-type cytochromes are absent; these include the positions of the haem site and the sixth ligand methionine, and the conserved lysine residues which interact with cytochrome oxidase (Nunn \& Anthony, 1988). This last feature is not unexpected since cytochrome $c_{\mathrm{L}}$ mediates 
electron transfer between methanol dehydrogenase and a typical Class I $c$-type cytochrome, which is the substrate for a cytochrome oxidase (Fig. 1).

Another periplasmic protein, known as the modifier protein or M-protein, interacts with methanol dehydrogenase. Formaldehyde can be oxidized by this enzyme, a reaction which must be strictly controlled, because in most methylotrophs carbon is assimilated at the oxidation level of formaldehyde. M-protein appears to regulate this by decreasing the affinity of methanol dehydrogenase for formaldehyde (Long \& Anthony, 1991).

The isolation and analysis of methanol oxidation (Mox) mutants has revealed that synthesis of the methanol oxidation system is a very complex process, requiring at least 25 genes. In summary, production of active periplasmic methanol dehydrogenase involves the following: synthesis and transport of PQQ; synthesis, transport and processing of prepeptides for the $\alpha$ and $\beta$ subunits; folding of these proteins in the periplasm; isomerization of prolines; insertion of disulphide bridges (including the special one at the active site); insertion of calcium and PQQ; wrapping $\beta$ chains around the $\alpha$ subunits; and association of the $\alpha \beta$ units to give the $\alpha_{2} \beta_{2}$ tetramer. Most of our knowledge of the genetics of this process has been obtained from investigation of $M$. extorquens AM1, Metbylobacterium organophilum XX, $M$. organophilum DSM760 and $P$. denitrificans, and Fig. 5 compares the organization of mox genes in these organisms. Table 1 lists the mox genes found to date in a variety of methylotrophs and their functions if known. A cluster of mox genes has also been identified in Metbylophilus methylotrophus but these genes have not been characterized (Dawson \& Goodwin, 1990). A model for the synthesis of active methanol dehydrogenase and cytochrome $c_{\mathrm{L}}$ is presented in Fig. 6, and the details of this model are discussed in the following sections.

\section{Structural genes}

In $M$. extorquens AM1 and $P$. denitrificans the structural genes encoding the $\alpha$ and $\beta$ subunits $(m \times a F$ and $m \times a I)$ are located in an operon together with $m \times a G$, the gene encoding cytochrome $c_{\mathrm{L}}$ and $m \times a J$, a gene of unknown function (Harms et al., 1987; Anderson et al., 1990; van Spanning et al., 1991). A putative $m \times a F$ promoter sequence (-35 -AAGACA-, - 10 -TAGAA-) has recently been identified (Barta \& Hanson, 1993; Chistoserdova et al., 1994). As expected, the polypeptide products of the structural genes contain typical signal sequences, which are cleaved on translocation to the periplasm (Fig. 2) (Nunn \& Anthony, 1988; Nunn et al., 1989; Anderson et al., 1990).

The DNA sequence of $m \times a J$ indicates that it encodes a precursor of a $30 \mathrm{kDa}$ periplasmic protein which does not have significant homology with any known protein. In Acetobacter methanolicus two forms of the methanol dehydrogenase have recently been isolated; one had the typical $\alpha_{2} \beta_{2}$ conformation, but the other contained a $32 \mathrm{kDa}$ protein whose $\mathrm{N}$-terminal amino acid sequence had homology with the predicted $m \times a J$ gene product
(Matsushita et al., 1993). It was therefore suggested that the MxaJ protein might be a component of methanol dehydrogenase, enabling it to function optimally in vivo. However, the possibility that $m \times a J$ encodes a molecular chaperone essential for the assembly of active methanol dehydrogenase, as previously suggested (van Spanning et al., 1991), could not be ruled out.

\section{Synthesis of PQQ}

PQQ is synthesized from glutamate and tyrosine (Houck et al., 1991) and must be transported into the periplasm before it can be incorporated into methanol dehydrogenase. At least seven $p q q$ genes are necessary for this process (Morris et al., 1994) (see Fig. 5 and Table 1). Three of these (pqqD, pqqG and pqqC of $M$. extorquens) have been sequenced and shown to have homology with $p q q$ genes of Klebsiella pneumoniae and Acinetobacter calcoaceticus, which both contain a PQQ-dependent glucose dehydrogenase (Morris et al., 1994). The functions of $p q q G$ and $p q q C$ are unknown but $p q q D$ probably encodes a peptide precursor of PQQ. The predicted $M$. extorquens peptide is slightly larger than the products of the corresponding genes in $K$. pneumoniae and $A$. calcoaceticus, comprising 29 amino acids, compared with $2 \hat{j}$ and 24 amino acids in the other two organisms. All three peptides contain a conserved sequence of seven amino acids, which includes glutamate and tyrosine residues, and these residues are probably the precursors of PQQ (Goosen et al., 1992; Meulenberg et al., 1992; Morris et al., 1994). Sequence analysis of the other genes in the $p q q$ region of $K$. pneumoniae indicates that one encodes a protease and another a dipeptidase (Meulenberg et al., 1992); it has been suggested that these enzymes are involved in processing the peptide precursor of PQQ and there are presumably homologues in the methylotrophs. The remaining $p q q$ gene products are probably required for further processing or for transporting PQQ to the periplasm.

\section{Processing and assembly of methanol dehydrogenase}

The $\alpha$ and $\beta$ subunits of methanol dehydrogenase are presumably transported into the periplasm by either the Sec or the SRP pathway. Once in the periplasm the $\alpha$ subunits must associate with PQQ and calcium and then assemble with the $\beta$ subunits to form an active enzyme. Because the PQQ is held by non-covalent bonds and is within the centre of the superbarrel it cannot be bonded directly to the unfolded $\alpha$ chain and it cannot be added after complete folding of this chain. By contrast, the apoenzymes of some related quinoproteins such as glucose dehydrogenase readily associate with added PQQ after formation of the fully folded form of the enzyme. These enzymes differ from methanol dehydrogenase in two ways - they do not have a $\beta$ subunit and consideration of their amino acid sequences indicates that they lack the surface fold that encloses the active site in methanol dehydrogenase, and prevents addition of PQQ into the $\alpha_{2} \beta_{2}$ tetrameric apoenzyme (Anthony et al., 1994).

At present little is known about the assembly of methanol dehydrogenase, but mutants of $M$. extorquens which are 


\section{Table 1. Genes involved in methanol oxidation in Gram-negative bacteria}

Genes involved in methanol oxidation were originally designated mox (methanol oxidation) genes. Recently a new nomenclature has been adopted (Lidstrom et al., 1994), but mox is still used as a collective symbol for methanol oxidation genes. Genes involved in PQQ synthesis have been designated $p q q$ genes and the remainder of the mox genes have been given a base symbol beginning with $m x$ for methanol oxidation. The third letter is determined by the chromosomal linkage group. Metbylobacterium species are pink facultative methylotrophs; Metbylophilus species are obligate methylotrophs; $P$. denitrificans grows as a facultative methylotroph on $\mathrm{C}_{1}$ compounds by oxidizing them to $\mathrm{CO}_{2}$ and then assimilating this by the autotrophic pathway. All the other genera listed are methanotrophs. MDH, Methanol dehydrogenase.

\begin{tabular}{|c|c|c|c|}
\hline \multicolumn{2}{|c|}{ Designation } & \multirow[t]{2}{*}{ Function } & \multirow[t]{2}{*}{ Organism $†$} \\
\hline New* & Old & & \\
\hline \multicolumn{4}{|c|}{ Group 1} \\
\hline$m \times a X$ & $\operatorname{mox} X$ & Regulation & Paracoccus denitrificans ${ }^{1}$ \\
\hline$m \times a Y$ & $\operatorname{mox} Y$ & Regulation & Paracoccus denitrificans ${ }^{1}$ \\
\hline$m \times a Z$ & $\operatorname{mox} Z$ & Regulation & Paracoccus denitrificans ${ }^{1}$ \\
\hline$m \times a W^{a}$ & $\operatorname{mox} W$ & Unknown (regulation?) & Metbylobacterium organopbilum ${ }^{2}$ \\
\hline$m \times a F$ & $\operatorname{mox} F$ & $\alpha$ subunit of $\mathrm{MDH}$ & $\begin{array}{l}\text { Metbylobacterium extorquens, }{ }^{3,4,5} \text { Metbylobacterium organophilum, } \\
\text { Paracoccus denitrificans, }{ }^{7} \text { Metbylosinus trichosporium, }{ }^{8} \text { Metbylococcus } \\
\text { capsulatus, }{ }^{9} \text { Metbylomonas albus, }{ }^{9} \text { Metbylomonas } \mathrm{A} 4,{ }^{10} \\
\text { Metbylosporovibrio methanica }\end{array}$ \\
\hline$m \times a J$ & $\operatorname{mox} J$ & $\begin{array}{l}\text { Third subunit of } \mathrm{MDH} \text {, or molecular } \\
\text { chaperone }\end{array}$ & $\begin{array}{l}\text { Methylobacterium extorquens, }{ }^{3,4,5} \text { Paracoccus denitrificans, }{ }^{12} \text { Metbylomonas } \\
{\text { A4 },{ }^{10} \text { Acetobacter methanolicus }}^{23}\end{array}$ \\
\hline$m \times a G$ & $\operatorname{mox} G$ & Cytochrome $c_{1}$ (cytochrome $c_{5511}$ ) & $\begin{array}{l}\text { Metbylobacterium extorquens, }{ }^{3,4,21} \text { Metbylobacterium organophilum, } \\
\text { Paracoccus denitrificans, }{ }^{12} \text { Metbylosporovibrio methanica, }{ }^{11} \text { Methylomonas } \\
\text { A4 }^{10}\end{array}$ \\
\hline$m \times a I$ & $\operatorname{mox} I$ & $\beta$ subunit of $\mathrm{MDH}$ & $\begin{array}{l}\text { Methylobacterium extorquens, }{ }^{22} \text { Metbylobacterium organopbilum, }{ }^{11} \text { Paracoccus } \\
\text { denitrificans, }{ }^{12} \text { Metbylosporovibrio methanica, }{ }^{11} \text { Methylomonas A } 4{ }^{10}\end{array}$ \\
\hline$m \times a \mathrm{R}$ & $\operatorname{mox} R$ & Unknown & Paracoccus denitrificans, ${ }^{12}$ Metbylomonas $\mathrm{A}^{10}$ \\
\hline$m \times a S$ & $\operatorname{mox} S$ & Unknown & Paracoccus denitrificans ${ }^{13}$ \\
\hline$m \times a A$ & $\operatorname{mox} A / A_{1}$ & Insertion of $\mathrm{Ca}^{2+}$ into $\mathrm{MDH}$ & Metbylobacterium extorquens, ${ }^{3,4,14}$ Methylobacterium organophilum ${ }^{11}$ \\
\hline$m \times a K$ & $\operatorname{mox} K / A_{2}$ & Insertion of $\mathrm{Ca}^{2+}$ into $\mathrm{MDH}$ & Metbylobacterium extorquens ${ }^{3,4,14}$ \\
\hline$m \times a L$ & $\operatorname{mox} L / A_{3}$ & Insertion of $\mathrm{Ca}^{2+}$ into $\mathrm{MDH}$ & Methylobacterium extorquens, ${ }^{3,4,14}$ Metbylobacterium organophilum ${ }^{11}$ \\
\hline$m \times a B$ & $\operatorname{mox} B$ & Regulation & Metbylobacterium extorquens, ${ }^{3,4,15}$ Metbylobacterium organophilum ${ }^{2}$ \\
\hline \multicolumn{4}{|c|}{ Group 2} \\
\hline$m \times b A^{b}$ & cou-6 & Unknown & Metbylobacterium extorquens ${ }^{16}$ \\
\hline$m \times b M$ & $\operatorname{mox} M$ & Regulation & Methylobacterium organophilum ${ }^{2}$ \\
\hline$m \times b D$ & $\operatorname{mox} D$ & Regulation & Methylobacterium extorquens, ${ }^{3,4,17}$ Metbylobacterium organopbilum ${ }^{2}$ \\
\hline$m \times b N$ & $\operatorname{mox} N$ & Regulation & Methylobacterium organophilum ${ }^{2}$ \\
\hline \multicolumn{4}{|c|}{ Group 3} \\
\hline$m \times c A^{c}$ & cou-1 & Unknown & Methylobacterium extorquens ${ }^{16}$ \\
\hline$m \times c E$ & $\operatorname{mox} E$ & Regulation & Methylobacterium extorquens, ${ }^{3,4}$ Metbylobacterium organophilum ${ }^{2}$ \\
\hline$m \times c Q$ & $\operatorname{mox} Q$ & Regulation & Metbylobacterium organophilum ${ }^{2}$ \\
\hline$m \times c U$ & $\operatorname{mox} U$ & Unknown & Metbylobacterium organophilum ${ }^{2}$ \\
\hline \multicolumn{4}{|c|}{ Group 4} \\
\hline$m x d R$ & $\operatorname{mox} \mathrm{R}$ & Unknown & Metbylobacterium extorquens ${ }^{18}$ \\
\hline$m x d S$ & $\operatorname{mox} S$ & Unknown & Methylobacterium extorquens ${ }^{18}$ \\
\hline \multicolumn{4}{|r|}{ (a) } \\
\hline$p q q A$ & $\operatorname{mox} C / P$ & Unknown & Metbylobacterium organopbilum DSM $760,{ }^{19}$ Metbylobacterium extorquens ${ }^{20}$ \\
\hline$p q q B$ & $\operatorname{mox} V$ & Unknown & Methylobacterium organophilum DSM760, ${ }^{19}$ Metbylobacterium extorquens ${ }^{20}$ \\
\hline$p q q C$ & $\operatorname{mox} T$ & Unknown & Metbylobacterium organophilum DSM760, ${ }^{19}$ Methylobacterium extorquens ${ }^{20}$ \\
\hline$p q q D$ & & PQQ precursor & Metbylobacterium organophilum DSM760, ${ }^{19}$ Methylobacterium extorquens ${ }^{20}$ \\
\hline pqqE & $\operatorname{mox} H$ & Unknown & Methylobacterium organophilum DSM760, ${ }^{19}$ Metbylobacterium extorquens ${ }^{20}$ \\
\hline pqqF & $\operatorname{mox} U$ & Unknown & Metbylobacterium organophilum DSM $760,{ }^{19}$ Metbylobacterium extorquens ${ }^{20}$ \\
\hline$p q q G$ & $\operatorname{moxO}$ & Unknown & Metbylobacterium organophilum DSM $760,{ }^{19}$ Metbylobacterium extorquens ${ }^{20}$ \\
\hline
\end{tabular}

* The following genes may be equivalent: ${ }^{\mathrm{a}} m \times a W$ of Methylobacterium organopbilum and $m \times a X, m \times a Y$ or $m \times a Z$ of $P$ aracoccus denitrificans; ${ }^{\mathrm{b}} m \times b A$ and $m \times b D, m \times b M$ or $m \times b N ;{ }^{c} m \times c A$ and $m \times c Q, m \times c U$ or $m \times c E$.

† Key references for the genes listed above are as follows: 1, Harms et al. (1993); 2, Xu et al. (1993); 3, Nunn \& Lidstrom (1986a); 4, Nunn \& Lidstrom (1986b); 5, Anderson et al. (1990); 6, Machlin \& Hanson (1988); 7, Harms et al. (1987); 8, Al-Taho et al. (1990); 9, Stephens et al. (1988); 10, Waechterbrulla et al. (1993); 11, Bastien et al. (1989); 12, van Spanning et al. (1991); 13, Harms (1993); 14, Richardson \& Anthony (1992); 15, Morris \& Lidstrom (1992); 16, Lee et al. (1991); 17, Day et al. (1990); 18, Laufer \& Lidstrom (1993); 19, Biville et al. (1989); 20, Morris et al. (1994); 21, Nunn \& Anthony (1988); 22, Nunn et al. (1989); 23, Matsushita et al. (1993). 


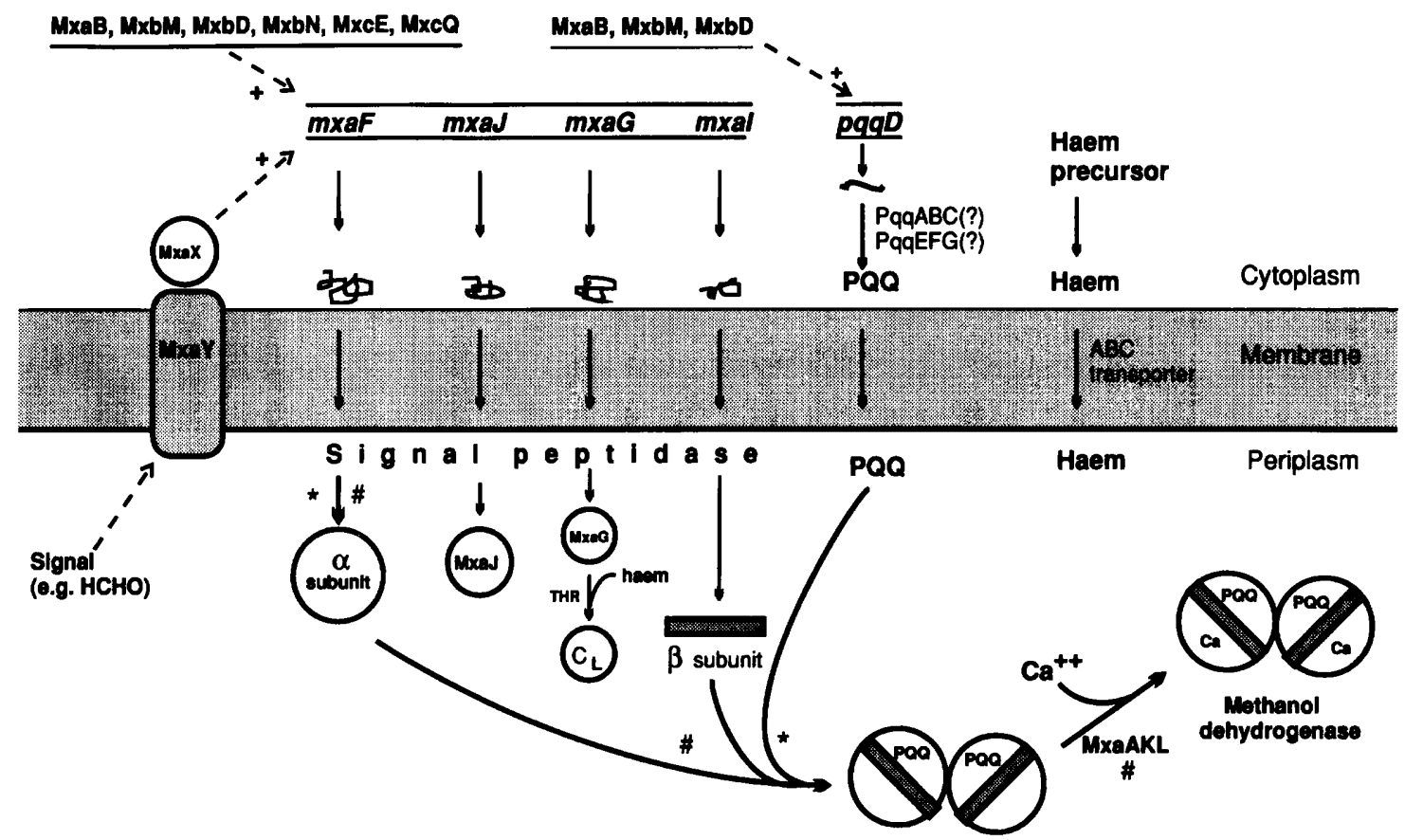

Fig. 6. A model for the expression of the mxaFJGI operon in $M$. extorquens, $P$. denitrificans and related bacteria. A signal is transmitted by way of MxaX and MxaY, leading to activation of the mxaF promoter; six other genes are also involved in activating this promoter. The resulting preproteins, PQQ and haem are transported into the periplasm where they are assembled into the proteins that are specifically involved in methanol oxidation-methanol dehydrogenase and cytochrome $c_{\mathrm{L}}$. Insertion of the haem requires prior reduction of MxaG by a thioredoxin-like protein (THR). The asterisk indicates two possible steps at which PQQ may be inserted. The \# indicates the possible steps in which the MxaAKL proteins may be involved in calcium incorporation; work with the mxaAKL mutants demonstrates, however, that the $\alpha_{2} \beta_{2}$ tetramer containing bound PQQ may be formed in the absence of these proteins.

defective in $m x a A, m \times a K$ or $m \times a L$ synthesize an inactive $\alpha_{2} \beta_{2}$ tetrameric methanol dehydrogenase which contains PQQ and which can be converted to the active form on incubation with calcium (Richardson \& Anthony, 1992). These genes must therefore be required for the insertion of calcium into methanol dehydrogenase and this step may occur after PQQ insertion. The products of $m \times a A, K$ and $L$ are probably periplasmic and they could function as a calcium carrier and/or stabilize methanol dehydrogenase in an appropriate conformation which can bind calcium.

There are presumably a number of other gene products required for the folding and assembly of methanol dehydrogenase. These could include the $\mathrm{MxaJ}$ protein (see above) and proteins encoded by some or all of the other mox genes whose function has not yet been elucidated (Table 1).

\section{Regulation of methanol dehydrogenase synthesis}

In Methylobacterium, methanol dehydrogenase is usually synthesized at low levels during growth on multicarbon substrates and induced on transfer to methanol medium. However, its synthesis is repressed during growth on a mixture of methanol and some heterotrophic substrates (Dunstan et al., 1972; O'Connor \& Hanson, 1977; McNerney \& O'Connor, 1980; Roitsch \& Stolp, 1986). In $P$. denitrificans, methanol dehydrogenase synthesis is more strictly regulated and it has been suggested that it is inhibited by a catabolite-repression-like mechanism and induced by formaldehyde, i.e. by the product of methanol oxidation (DeVries et al., 1988). Thus regulation of the production of methanol dehydrogenase is complex and understanding the mechanism will require detailed genetic studies; these will be greatly helped by the recent development of promoter probe vectors (Morris \& Lidstrom, 1992; $\mathrm{Xu}$ et al., 1993). One such vector has been used to demonstrate that the promoters of three mox genes were activated when $M$. organophilum was transferred from succinate to methanol medium. The three promoters investigated were for $m \times a F$ (which codes for the $\alpha$ subunit), $m \times a W$ (a gene of unknown function which is located upstream of $m \times a F$ and transcribed in the opposite direction) and $m \times c U$ (whose function is also unknown). It is likely that the promoters of some of the other mox genes are also regulated by methanol. It has been shown that activation of these methanol-regulated promoters requires one or more of the following regulatory genes: $m \times a B, m \times b D, m \times b M, m \times b N, m \times c E$ and $m \times 2 Q$ (Xu et al., 1993). Three of these genes - mxaB, $m \times b M$ and $m \times b D-$ also regulate transcription of $p q q D$, but there is evidence that other mechanisms play a major part in the control of PQQ synthesis; these may involve transcriptional regulation of other $p q q$ genes and/or posttranscriptional modification of one or more of the $p q q$ gene products (Ramamoorthi \& Lidstrom, 1995). 
The products of the mox regulatory genes have not been isolated but some of them may function as part of a signal transduction system. There is evidence that such a system operates in $P$. denitrificans and that three genes - mxaX, $m \times a Y$ and $m \times a Z$ - are involved (Harms $e$ t al., 1993). They are located upstream of $m \times a F$ and transcribed in the opposite direction. The $m \times a Z$ and $m \times a Y$ genes form one transcriptional unit, possibly with $m \times a X$ as well, and one of these genes may be equivalent to the $m \times a W$ gene of $M$. organophilum (Lidstrom et al., 1994).

The predicted amino acid sequences of $\mathrm{MxaY}$ and $\mathrm{MxaX}$ are homologous with the protein histidine kinases and response regulators of other bacterial signal transduction regulatory systems (for review of these see Parkinson, 1993). It has been suggested by Harms et al. (1993) that $\mathrm{MxaY}$ is a membrane histidine protein kinase which senses a signal (they propose this is formaldehyde) and is then autophosphorylated; $\mathrm{MxaY}$ then interacts with $\mathrm{MxaX}$, which can then activate transcription of $m \times a F$. The predicted amino acid sequence of the $m \times a Z$ gene product indicates that it is a membrane protein with one transmembrane segment but it has no homology with any known proteins and its function is unclear. It is not essential for the production of methanol dehydrogenase but may have a role in signal recognition and thus be required for maximum activation of the $m \times a F J G I$ operon.

\section{Production of cytochrome $c_{L}$}

Haem biosynthesis. There are two routes for the synthesis of 5-aminolevulinic acid (ALA), which is the precursor of the porphyrin skeleton of haem. The first involves the condensation of succinyl coenzyme $\mathrm{A}$ and glycine, which is catalysed by ALA synthase, and this pathway operates in $P$. denitrificans (Page \& Ferguson, 1994). In the alternative $C_{5}$ pathway ALA is formed from glutamate, with glutamyl tRNA ${ }^{\text {Glu }}$ as the first intermediate; as might be predicted, this pathway occurs in the obligate methylotroph $M$. metbylotropbus, which cannot make succinate via the TCA cycle since it lacks 2oxoglutarate dehydrogenase (Lloyd et al., 1993).

Post-translational processing of pre-cytochrome $c_{L}$. This requires a number of gene products which are also needed for the production of other $c$-type cytochromes. Mutants of $M$. extorquens and $P$. denitrificans which are unable to make any $c$-type cytochromes have been isolated (Anthony, 1975; Willison \& John, 1979; Harms et al., 1985; Oozeer et al., 1993), the Methylobacterium mutants falling into at least three complementation groups (Oozeer et al., 1993). However, by analogy with Rhodobacter capsulatus and Bradyrbizobium japonicum, we would expect at least nine genes to be essential for the synthesis of cytochrome $c_{\mathrm{L}}$ in addition to its structural gene, $m \times a G$ (Ramseier et al., 1991; Beckman et al., 1992; Ritz et al., 1993; Beckman \& Kranz, 1993; Thonymeyer et al., 1994a, b).

The predicted precursors of the $c$-cytochromes, including cytochrome $c_{L}$, have typical signal sequences, with signal peptidase I cleavage sites (Fig. 2), and they are presumably transferred across the membrane by the Sec or SRP pathway. One of the key steps in the processing of $c$-type cytochromes is the attachment of the haem group, and there is evidence from studies of mutants of $P$. denitrificans which are unable to synthesize cytochrome $c d_{1}$ and $c_{550}$ that the apoproteins and haem are transported separately to the periplasm where they then combine (Page \& Ferguson, 1989, 1990). Genes essential for cytochrome $c$ biogenesis which are predicted to encode the components of an $A B C$ transporter (which may be a specific haem transporter) have been identified in $B$. japonicum, $R$. capsulatus and E. coli (Ramseier et al., 1991; Beckman et al., 1992; Poole et al., 1994).

In mitochondria the addition of haem to cytochrome $c$ is catalysed by haem lyase but this enzyme has not yet been identified in bacteria. The haem-binding site (Cys-X-XCys-His) of the cytochrome $c$ must be reduced before haem attachment can take place and a thioredoxin-like protein is probably required for this (Beckman \& Kranz, 1993; Thonymeyer et al., 1994b; Sambongi \& Ferguson, 1994).

\section{Model for the synthesis of the 'methanol oxidase' system}

A model for the synthesis of active methanol dehydrogenase and cytochrome $c_{\mathrm{L}}$ is presented in Fig. 6. An environmental signal is recognized and transmitted by the $\mathrm{MxaX}-\mathrm{MxaY}$ signal transduction system, resulting in the activation of the $m \times a F$ promoter. At least six other genes $(m \times a B, m \times b D, m \times b M, m \times b N, m \times c E$ and $m \times c Q)$ are also involved in regulation of this promoter. The $m \times a F J G I$ operon is then expressed and the precursors of the $\alpha$ and $\beta$ subunits of methanol dehydrogenase and cytochrome $c_{\mathrm{L}}$ are transported across the cytoplasmic membrane, with release of the signal peptides.

PQQ is synthesized in the cytoplasm from a peptide precursor encoded by $p q q D$ and then transported into the periplasm. At least three genes $(m \times a B, m \times b D$ and $m \times b M)$ regulate transcription of $p q q D$ and at least six other genes (pqqABCEFG) encode products essential for PQQ production; they probably include a dipeptidase and a protease involved in processing the precursor. Haem is also synthesized in the cytoplasm and then transported to the periplasm by an $\mathrm{ABC}$ transporter.

In the periplasm the $\alpha$ and $\beta$ subunits of methanol dehydrogenase fold and assemble, and PQQ and calcium are inserted. Several gene products are likely to be involved in this process, including the $\mathrm{MxaA}, \mathrm{MxaK}$ and $\mathrm{MxaL}$ proteins, which are essential for the insertion of calcium. Attachment of haem to apo-cytochrome $c_{\mathrm{L}}$ also occurs in the periplasm and a thioredoxin-like protein is required to maintain the haem-binding site in the reduced state.

\section{Synthesis of the methylamine oxidation system}

Methylamine is oxidized to formaldehyde by methylamine dehydrogenase, which was the first quinoprotein to have its structure determined by X-ray crystallography (Vellieux et al., 1989). Remarkably, this enzyme is similar 


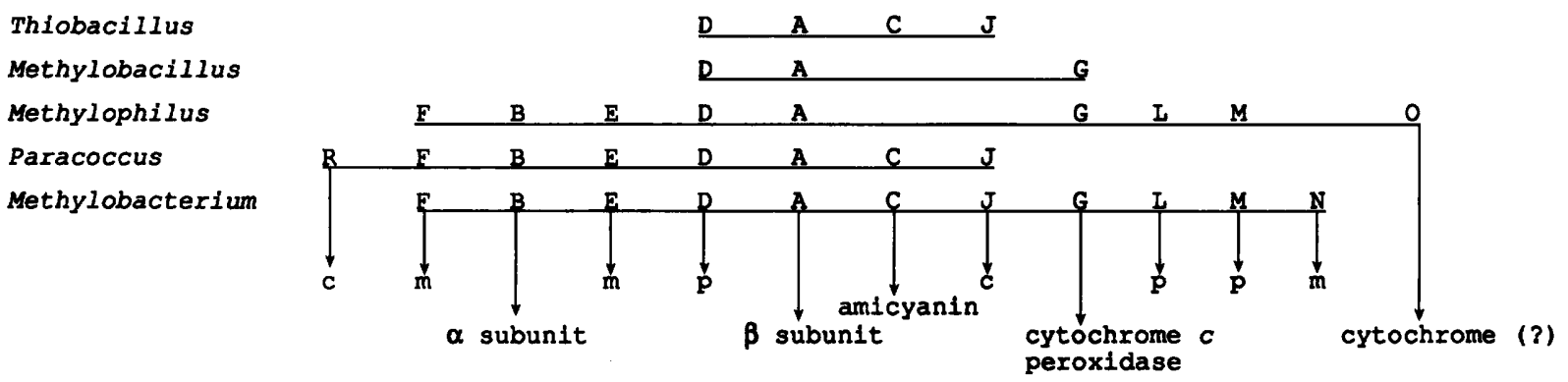

Fig. 7. Organization of the mau genes in methylotrophs. The mauB and mauA genes encode the $\alpha$ (heavy) and $\beta$ (light) subunits of methylamine dehydrogenase. The mauO gene probably encodes a c-type cytochrome that replaces amicyanin as electron acceptor for methylamine dehydrogenase in $M$. methylotrophus W3A1. Membrane, periplasmic and cytoplasmic proteins are represented by $m, p$ and $c$, respectively. Data are taken from the following sources: Chistoserdov et al. (1994a) (for M. extorquens AM1); Chistoserdov et al. (1994b) (for M. methylotrophus W3A1); Ubbink et al. (1991) (for $T$. versutus); and Lidstrom \& Chistoserdov (1993) (for a review and for $M$. flagellatum KT and $P$. denitrificans).

to methanol dehydrogenase in having an unusual (but different) quinone prosthetic group, an $\alpha_{2} \beta_{2}$ tetrameric structure, and large $(\alpha)$ subunits having a propeller fold arranged to form a superbarrel. The $\alpha$ subunit of methylamine dehydrogenase $(40 \mathrm{kDa}$ in $M$. extorquens) differs from that of methanol dehydrogenase, however, in having only a sevenfold radial symmetry and a centre occupied by amino acid residues and not by the prosthetic group (Vellieux et al., 1989; Chen et al., 1992b). This is not PQQ but another quinone structure, tryptophan tryptophylquinone (TTQ) (Fig. 3), which is formed by joining two tryptophan residues of the $\beta$ subunit (about $14 \mathrm{kDa}$ in $M$. extorquens) which is tightly held together by six disulphide bridges (McIntire et al., 1991; Chen et al., 1991).

Methylamine dehydrogenase passes electrons to a specific electron acceptor, which is usually the blue copper protein amicyanin (about $12 \mathrm{kDa}$ in $M$. extorquens) (for reviews see Anthony, 1993a; Davidson, 1993). Exciting possibilities for analysis of the interaction of these two proteins have recently arisen with the description of the X-ray structure of the complex (Chen et al., 1992a). The oxidation of amicyanin by the terminal oxidase is mediated either by a $c$-type cytochrome or by a second blue copper protein (Fig. 1) (Anthony, 1993a). In some methylotrophs blue copper proteins have not been detected and it is assumed that a Class I cytochrome $c$ mediates directly between the methylamine dehydrogenase and the oxidase.

In $M$. extorquens a cluster of eleven genes, designated mau genes, has been identified (Fig. 7), eight of which - mauF, $\operatorname{man} B, \operatorname{man} E, \operatorname{man} D, \operatorname{man} A, \operatorname{man} C, \operatorname{man} G$, and $\operatorname{man} L-$ are essential for growth on methylamine (Chistoserdov et al., 1994a ; Lidstrom \& Chistoserdov, 1993). Similar mau gene clusters are found in $P$. denitrificans, Thiobacillus versutus, Metbylobacillus flagellatum $\mathrm{KT}$ and $M$. metbylotropbus (Chistoserdov et al., 1992, 1994b; Ubbink et al., 1991). In $P$. denitrificans an additional gene essential for methylamine utilization - mau $\mathrm{R}$ - has recently been described; it is located next to mauF, but transcribed in the opposite direction (van Spanning et al., 1994). A model for synthesis of active methylamine dehydrogenase and amicyanin is presented in Fig. 8, and the details of the model are discussed in the following sections.

\section{Structural genes}

The $\operatorname{mau} B$ and $\operatorname{mau} A$ genes encode the large and small subunits of methylamine dehydrogenase. As expected, the predicted gene products of mau $A$ and mauB include a signal peptide, but that for MauA is longer than normal (57 amino acids compared with the usual 20-28) and has two other unusual features (Fig. 2) (Chistoserdov \& Lidstrom, 1991). Before the region of positively charged amino acids at the $\mathrm{N}$-terminal end there are 13 residues which are mostly hydrophilic, and near the peptidase recognition site is a region of positively charged amino acids, which would be expected to slow down translocation. This signal sequence does not function in E. coli when fused to pho $A$ (the alkaline phosphatase reporter gene), and presumably has a special function in the processing of the $\beta$ subunit and/or its association with the $\alpha$ subunit. A similar signal sequence is present in the predicted polypeptide precursors of the $\beta$ subunits of $T$. versutus, P. denitrificans and M. metbylotrophus (Ubbink et al., 1991; Chistoserdov et al., 1992, 1994b).

The man $C$ gene encodes the precursor of amicyanin, which has a typical signal peptide. Not surprisingly, synthesis of amicyanin does not occur in the absence of copper in the medium, but there is evidence that iron is also essential for its production (Auton \& Anthony, 1989). M. metbylotrophus W3A1 does not contain a mauC gene and it has been suggested that a cytochrome substitutes for amicyanin as the primary electron acceptor; this is possibly encoded by mau $\mathrm{O}$, which is found at the end of the mau cluster in this organism (Chistoserdov $e t$ al., 1994b).

\section{Synthesis of the prosthetic group, TTQ}

TTQ is derived from two tryptophan residues in the $\beta$ subunit (Fig. 3) and it has been suggested that its synthesis involves formation of an indole 6,7-dione or 6,7hydroxyindole intermediate on one tryptophan residue, followed by cross-linking of the two residues (Lidstrom 


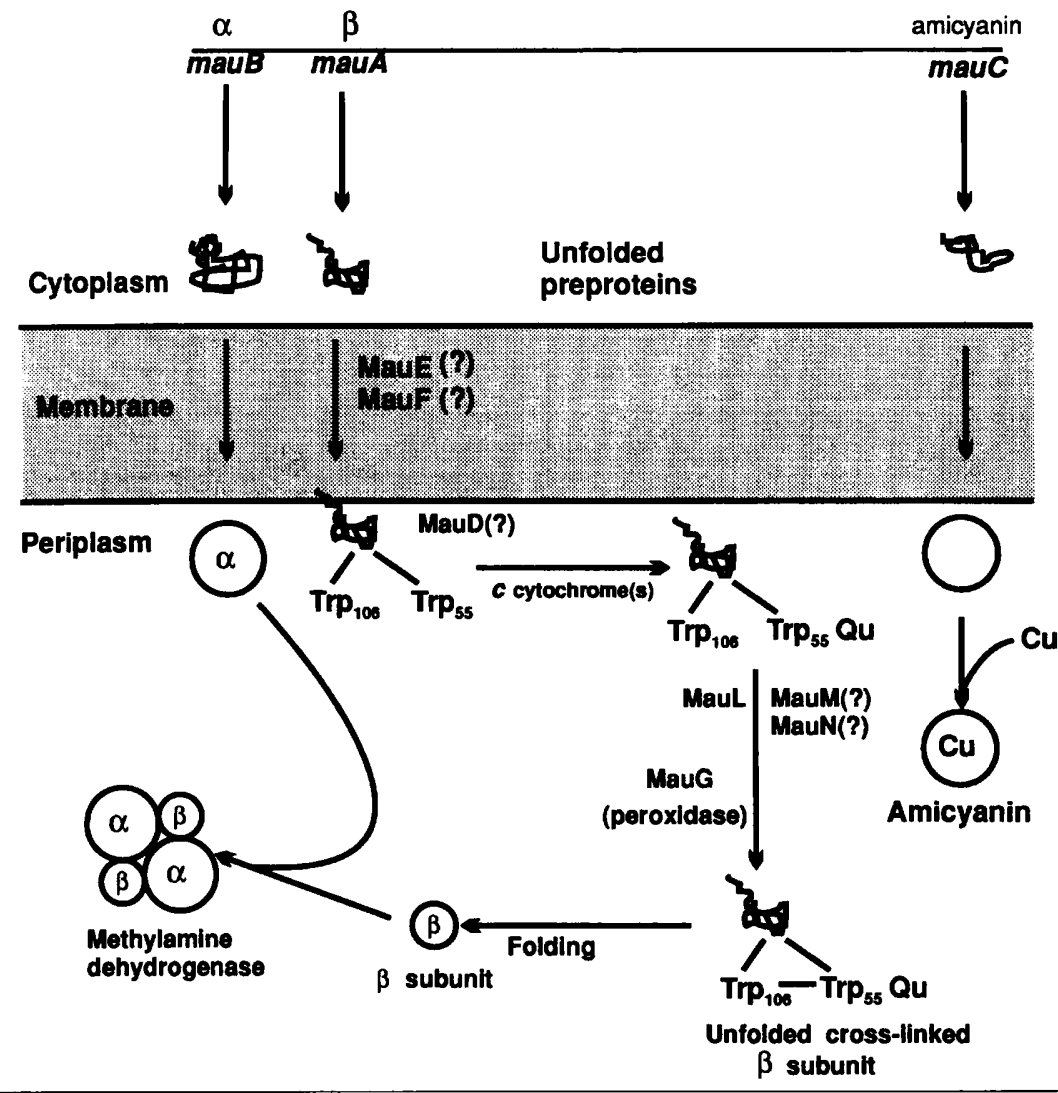

Fig. 8. A model for the expression of the mau genes involved in synthesis of methylamine dehydrogenase and its specific electron acceptor amicyanin. The preprotein for the small $\beta$ subunit (MauA) has an exceptionally long signal sequence which slows down its translocation and release. It is possible that some oxidation of the prosthetic group tryptophan (see Fig. 3) occurs on the preprotein in the cytoplasm, but the final production of the quinone structure $\left(\operatorname{Trp}_{106}-\operatorname{Trp}_{55} \mathrm{Qu}\right)$ is catalysed in the periplasm.
\& Chistoserdov, 1993; Page \& Ferguson, 1993). A role for a $c$-type cytochrome in this pathway was first indicated by the observation that mutants unable to produce any $c$ type cytochromes are also impaired in the synthesis of active methylamine dehydrogenase (Anthony, 1975; Oozeer et al., 1993). It has been shown subsequently by Page \& Ferguson (1993) that although such mutants are able to synthesize the $\alpha$ and $\beta$ subunits, which are then transported to the periplasm, the $\beta$ subunits do not react with a quinone stain. They therefore suggested that a $c$ type cytochrome-linked hydroxylase catalyses at least one step in quinone formation, and that this reaction occurs in the periplasm.

The $\operatorname{man} G$ gene probably encodes a $c$-type cytochrome since the predicted amino acid sequence of its gene product has $29 \%$ homology with the cytochrome $c$ peroxidase of Pseudomonas aeruginosa (Chistoserdov et al., 1994a). However, this cytochrome is not essential for quinone production since mutants defective in $\operatorname{man} G$ make the $\beta$ subunit, which reacts with a quinone stain. Peroxidases are known to cross-link indole groups and it has therefore been suggested that the MauG protein is involved in cross-linking the two tryptophan residues (Chistoserdov et al., 1994a). The maul gene encodes a periplasmic protein which is also probably involved in cross-linking since mutants defective in this gene have a similar phenotype to MauG mutants. Further work is required to confirm this and to elucidate the other steps in TTQ formation.

The DNA sequences of mauM and $\operatorname{man} N$, neither of which is essential for methylamine utilization, indicate that they encode periplasmic and membrane proteins, respectively. They both have regions of homology with ferredoxin genes, and may encode iron-sulphur proteins involved in the postulated peroxidase reaction. Presumably other proteins provide their function in the mutants lacking them.

\section{Processing and assembly of methylamine dehydrogenase}

Further processing of the subunits of methylamine dehydrogenase and their assembly in the periplasm to form the mature enzyme has not been studied. However, predictions from DNA sequence data indicate that the $m a u F$ and mauE genes of $M$. extorquens encode membrane proteins and that mauD encodes a periplasmic protein (Fig. 7). Mutants defective in these genes do not contain the $\beta$ subunit and it has therefore been suggested that they are involved in the transport, processing and/or stabilization of this subunit (Lidstrom \& Chistoserdov, 1993; Chistoserdov et al., 1994a). The precursor of the MauD protein of $M$. extorquens is unusual in that it has a lipoprotein peptide signal sequence (Fig. 2), but the equivalent preprotein of $M$. metbylotrophus has a typical signal peptide.

\section{Regulation of methylamine dehydrogenase synthesis}

Methylamine dehydrogenase and amicyanin are induced when cells are grown in medium containing methylamine or methylated amines and there is evidence that, in the obligate methylotroph $M$. metbylotrophus, methylamine 
dehydrogenase is repressed when methanol or $\mathrm{NH}_{4}^{+}$is provided as an alternative carbon or nitrogen source (Dunstan et al., 1972; Large \& Haywood, 1981; Auton \& Anthony, 1989; Dawson et al., 1990). The predicted Mau J protein is cytoplasmic and, because it is not essential for growth on methylamine, it has been postulated to have a regulatory role (Chistoserdov et al., 1994a). However, there was no evidence to support this hypothesis since Mau J mutants had levels of methylamine dehydrogenase activity similar to those in wild-type bacteria. The mauR gene described recently in $P$. denitrificans encodes a protein with homology to the LysR type transcriptional activators and is a better candidate for a regulatory gene in the methylamine oxidase system (van Spanning et al., 1994).

\section{A model for the synthesis of the 'methylamine oxidase' system}

A model for the synthesis of methylamine dehydrogenase and amicyanin is shown in Fig. 8. The $\operatorname{man} B, \operatorname{man} A$ and man $C$ genes are expressed to form precursors of the $\alpha$ and $\beta$ subunits of methylamine dehydrogenase and amicyanin. These are transported across the cytoplasmic membrane, although the abnormal signal sequence on the precursor of the $\beta$ subunit probably slows down its transport. MauF and MauE, which are membrane proteins, may play a role in the transport process.

Although the exact pathway of TTQ synthesis is not known, at least two stages occur in the periplasm: the first is a cytochrome- $c$-dependent step essential for the formation of a quinone derivative of one of the tryptophan residues, and the second is a peroxidase reaction, catalysed by MauG, resulting in cross-linking of the two tryptophan residues which make up TTQ. The MauL protein is also needed for this step and the ferredoxin-like proteins encoded by mauM and mau $N$ may produce hydrogen peroxide for the peroxidase reaction. The MauD protein may be required to stabilize the $\beta$ subunit during TTQ formation. Assembly of the methylamine dehydrogenase subunits to form an active enzyme occurs in the periplasm and presumably involves some as yet unidentified gene products.

\section{Acknowledgements}

Work in the authors' laboratories was supported by the SERC, BBSRC and The Wellcome Trust.

\section{References}

Al-Taho, N. M., Cornish, A. \& Warner, P. J. (1990). Molecular cloning of the methanol dehydrogenase structural gene from Metbylosinus trichosporium OB3b. Curr Microbiol 20, 153-157.

Anderson, D. J., Morris, C. J., Nunn, D. N., Anthony, C. \& Lidstrom, M. E. (1990). Nucleotide sequence of the Metbylobacterium extorquens AM1 moxF and moxJ genes involved in methanol oxidation. Gene 90, 173-176.

Anthony, C. (1975). The microbial metabolism of $C_{1}$ compounds: the cytochromes of Pseudomonas AM1. Biochem J 146, 289-298.

Anthony, C. (1982). The Biocbemistry of Metbylotrophs. London: Academic Press.
Anthony, C. (1986). The bacterial oxidation of methane and methanol. Adv Microb Pbysiol 27, 113-210.

Anthony, C. (1992). The c-type cytochromes of methylotrophic bacteria. Biochim Biopbys Acta 1099, 1-15.

Anthony, C. (1993a). The role of quinoproteins in bacterial energy transduction. In Principles and Applications of Quinoproteins, pp. 223-244. Edited by V. L. Davidson. New York: Marcel Dekker.

Anthony, C. (1993b). Methanol dehydrogenase in Gram-negative bacteria. In Principles and Applications of Quinoproteins, pp. 17-45. Edited by V. L. Davidson. New York: Marcel Dekker.

Anthony, C., Ghosh, M. \& Blake, C. C. F. (1994). The structure and function of methanol dehydrogenase and related PQQ-containing quinoproteins. Biochem $J$ 304, 665-674.

Auton, K. A. \& Anthony, C. (1989). The role of cytochromes and blue copper proteins in growth of an obligate methylotroph on methanol and methylamine. J Gen Microbiol 135, 1923-1931.

Bardwell, J. C. A. (1994). Building bridges: disulphide bond formation in the cell. Mol Microbiol 14, 199-205.

Bardwell, J. C. A. \& Beckwith, J. (1993). The bonds that tiecatalyzed disulfide bond formation. Cell 74, 769-771.

Barta, T. M. \& Hanson, R. S. (1993). Genetics of methane and methanol oxidation in Gram-negative methylotrophic bacteria. Antonie Leeuwenhoek 64, 109-120.

Bastien, C. A., Machlin, S. M., Zhang, Y., Donaldson, K. \& Hanson, R. S. (1989). Organization of genes required for the oxidation of methanol to formaldehyde in three type II methylotrophs. Appl Environ Microbiol 55, 3124-3130.

Beardmore-Gray, M., O'Keeffe, D. T. \& Anthony, C. (1983). The methanol: cytochrome $c$ oxidoreductase activity of methylotrophs. $J$ Gen Microbiol 129, 923-933.

Beckman, D. L. \& Kranz, R. G. (1993). Cytochromes $c$ biogenesis in a photosynthetic bacterium requires a periplasmic thioredoxin-like protein. Proc Natl Acad Sci US A 90, 2179-2183.

Beckman, D. L., Trawick, D. R. \& Kranz, R. G. (1992). Bacterial cytochromes $c$ biogenesis. Genes \& Dev 6, 268-283.

Biville, F., Turlin, E. \& Gasser, F. (1989). Cloning and genetic analysis of six pyrroloquinoline quinone biosynthesis genes in Metbylobacterium organopbilum DSM760. J Gen Microbiol 135, 2917-2929.

Blake, C. C. F., Ghosh, M., Harlos, K., Avezoux, A. \& Anthony, C. (1994). The active site of methanol dehydrogenase contains a disulphide bridge between adjacent cysteine residues. Nature Struct Biol 1, 102-105.

Brandner, J. P. \& Donohue, T. J. (1994). The Rhodobacter sphaeroides cytochrome $c_{2}$ signal peptide is not necessary for export and heme attachment. J Bacteriol 176, 602-609.

Chen, L. Y., Mathews, F. S., Davidson, V. L., Huizinga, E. G., VellieuX, F. M. D., Duine, J. A. \& Hol, W. G. J. (1991). Crystallographic investigations of the tryptophan-derived cofactor in the quinoprotein methylamine dehydrogenase. FEBS Lett 287, 163-166.

Chen, L. Y., Durley, R., Poliks, B. J., Hamada, K., Chen, Z. W., Mathews, F. S., Davidson, V. L., Satow, Y., Huizinga, E., Vellieux, F. M. D. \& Hol, W. G. J. (1992a). Crystal structure of an electrontransfer complex between methylamine dehydrogenase and amicyanin. Biochemistry 31, 4959-4964.

Chen, L. Y., Mathews, F. S., Davidson, V. L., Huizinga, E. G., Vellieux, F. M. D. \& Hol, W. G. J. (1992b). 3-Dimensional structure of the quinoprotein methylamine dehydrogenase from Paracoccus denitrificans determined by molecular replacement at $2.8 \AA$ resolution. Proteins Struct Funct Genet 14, 288-299. 
Chistoserdov, A. Y. \& Lidstrom, M. E. (1991). The small-subunit polypeptide of methylamine dehydrogenase from Metbylobacterium extorquens AM1 has an unusual leader sequence. J Bacteriol 173, 5909-5913.

Chistoserdov, A. Y., Boyd, J., Mathews, F. S. \& Lidstrom, M. E. (1992). The genetic organization of the man gene cluster of the facultative autotroph Paracoccus denitrificans. Biochem Biophys Res Commun 184, 1225-1234.

Chistoserdov, A. Y., Chistoserdova, L. V., McIntire, W. S. \& Lidstrom, M. E. (1994a). Genetic organization of the mau gene cluster in Metbylobacterium extorquens AM1: complete nucleotide sequence and generation and characteristics of mau mutants. $J$ Bacteriol 176, 4052-4065.

Chistoserdov, A. Y., Mclntire, W. S., Mathews, F. S. \& Lidstrom, M. E. (1994b). Organization of the methylamine utilization (mau) genes in Metbylophilus metbylotrophus W3A1. J Bacteriol 176, 4073-4080.

Chistoserdova, L., Kuhn, M. \& Lidstrom, M. E. (1994). Identification of a promoter region for $m \times a F(\operatorname{mox} F)$ from the type I methanotroph, Metbylomonas albus bG8. FEMS Microbiol Lett 121, 343-348

Dalbey, R. E. \& von Heijne, G. (1992). Signal peptidases in prokaryotes and eukaryotes - a new protease family. Trends Biochem Sci 17, 474-478.

Davidson, V. L. (1993). Methylamine dehydrogenase. In Principles and Applications of Quinoproteins, pp. 73-95. Edited by V. L. Davidson. New York: Marcel Dekker.

Dawson, A. \& Goodwin, P. M. (1990). Investigation of mutants of Metbylophilus methylotrophus which are defective in methanol oxidation. $J$ Gen Microbiol 136, 1373-1380.

Dawson, A., Southgate, G. \& Goodwin, P. M. (1990). Regulation of methanol and methylamine dehydrogenases in Metbylophilus metbylotrophus. FEMS Microbiol Lett 68, 93-96.

Day, D. J., Nunn, D. N. \& Anthony, C. (1990). Characterization of a novel soluble $c$-type cytochrome in a moxD mutant of Metbylobacterium extorquens AM1. J Gen Microbiol 136, 181-188.

DeVries, G. E., Harms, N., Maurer, K., Papendrecht, A. \& Stouthamer, A. H. (1988). Physiological regulation of Paracoccus denitrificans methanol dehydrogenase synthesis and activity. $J$ Bacteriol 170, 3731-3737.

Dunstan, P. M., Anthony, C. \& Drabble, W. T. (1972). The role of glyoxylate, glycollate and acetate in the growth of Pseudomonas AM1 on ethanol and C-1 compounds. Biochem J 128, 107-115.

Ferguson, S. J. (1988). Periplasmic electron transport reactions. In Bacterial Energy Transduction, pp. 151-182. Edited by C. Anthony. London: Academic Press.

Ghosh, M., Anthony, C., Harlos, K., Goodwin, M. G. \& Blake, C. C. F. (1995). The refined structure of the quinoprotein methanol dehydrogenase from Metbylobacterium extorquens at $1.94 \AA$. Structure 3, 177-187.

Goosen, N., Huinen, R. G. M. \& Vandeputte, P. (1992). A $24-$ amino-acid polypeptide is essential for the biosynthesis of the coenzyme pyrrolo-quinoline-quinone. J Bacteriol 174, 1426-1427.

Hardy, S. J. S. \& Randall, L. L. (1993). Recognition of ligands by SecB, a molecular chaperone involved in bacterial protein export. Pbilos Trans R Soc Lond B Biol Sci 339, 87-98.

Harms, N. (1993). Genetics of methanol oxidation in Paracoccus denitrificans. In Microbial Growth on $C_{1}$ Compounds, pp. 235-244. Edited by J. C. Murrell \& D. P. Kelly. Andover: Intercept.

Harms, N., DeVries, G. E., Maurer, K., Veltkamp, E. \& Southamer, A. H. (1985). Isolation and characterisation of Paracoccus denitrificans mutants with defects in the metabolism of one-carbon compounds. $J$ Bacteriol 164, 1064-1070.

Harms, N., DeVries, G. E., Maurer, K., Hoogendijk, J. \& Stouthamer, A. H. (1987). Isolation and nucleotide sequence of the methanol dehydrogenase structural gene from Paracoccus denitrificans. J Bacteriol 169, 3969-3975.

Harms, N., Reijnders, W. N. M., Anazawa, H., Vanderpalen, C. J. N. M., van Spanning, R. J. M., Oltmann, L. F. \& Stouthamer, A. H. (1993). Identification of a 2-component regulatory system controlling methanol dehydrogenase synthesis in Paracoccus denitrificans. Mol Microbiol 8, 457-470.

Houck, D. R., Hanners, J. L. \& Unkefer, C. J. (1991). Biosynthesis of pyrroloquinoline quinone. 2 . Biosynthetic assembly from glutamate and tyrosine. J Am Chem Soc 113, 3162-3166.

Large, P. J. \& Haywood, G. W. (1981). Methylophilus metbylotrophus grows on methylated amines. FEMS Microbiol Lett 11, 207-209.

Laufer, K. \& Lidstrom, M. E. (1993). Regulation and expression of bacterial quinoproteins. In Principles and Applications of Quinoproteins, pp. 193-222. Edited by V. L. Davidson. New York: Marcel Dekker.

Lee, K. E., Stone, S., Goodwin, P. M. \& Holloway, B. W. (1991). Characterization of transposon insertion mutants of Metbylobacterium extorquens AM1 (Metbylobacterium strain AM1) which are defective in methanol oxidation. J Gen Microbiol 137, 895-904.

Lidstrom, M. E. \& Chistoserdov, A. Y. (1993). Molecular biology and genetics of methylamine dehydrogenase. In Microbial Growth on $C_{1}$ Compounds, pp. 381-400. Edited by J. C. Murrell \& D. P. Kelly. Andover: Intercept.

Lidstrom, M. E., Anthony, C., Biville, F., Gasser, F., Goodwin, P., Hanson, R. S. \& Harms, N. (1994). New unified nomenclature for genes involved in the oxidation of methanol in Gram-negative bacteria. FEMS Microbiol Lett 117, 103-106.

Liu, J. \& Walsh, C. T. (1990). Peptidyl-prolyl cis-trans-isomerase from Eschericbia coli: a periplasmic homolog of cyclophilin that is not inhibited by cyclosporin A. Proc Natl Acad Sci USA 87, 4028-4032.

Lloyd, A. J., Weitzman, P. D. \& Soll, D. (1993). Incomplete citric acid cycle obliges aminolevulinic acid synthesis via the $C_{5}$ pathway in a methylotroph. J Gen Microbiol 139, 2931-2938.

Loferer, H. \& Hennecke, H. (1994). Protein disulphide oxidoreductases in bacteria. Trends Biocbem Sci 19, 169-171.

Long, A. R. \& Anthony, C. (1991). The periplasmic modifier protein for methanol dehydrogenase in the methylotrophs Metbylophilus metbylotropbus and Paracoccus denitrificans. J Gen Microbiol 137, 2353-2360.

Machlin, S. M. \& Hanson, R. S. (1988). Nucleotide sequence and transcriptional start site of the Metbylobacterium organophilum XX methanol dehydrogenase structural gene. J Bacteriol 170, 4739-4747.

Matsushita, K., Takahashi, K. \& Adachi, O. (1993). A novel quinoprotein methanol dehydrogenase containing an additional 32 kilodalton peptide purified from Acetobacter methanolicus identification of the peptide as a moxJ product. Biochemistry 32, 5576-5582

Mcintire, W. S., Wemmer, D. E., Chistoserdov, A. \& Lidstrom, M. E. (1991). A new cofactor in a prokaryotic enzyme - tryptophan tryptophylquinone as the redox prosthetic group in methylamine dehydrogenase. Science 252, 817-824.

McNerney, T. \& O'Connor, M. L. (1980). Regulation of enzymes associated with $\mathrm{C}-1$ metabolism in three facultative methylotrophs. Appl Environ Microbiol 40, 370-375. 
Meulenberg, J. J. M., Sellink, E., Riegman, N. H. \& Postma, P. W. (1992). Nucleotide sequence and structure of the Klebsiella pneumoniae pqq operon. Mol \& Gen Genet 232, 284-294.

Morris, C. J. \& Lidstrom, M. E. (1992). Cloning of a methanolinducible $\operatorname{mox} F$ promoter and its analysis in $\operatorname{mox} B$ mutants of Metbylobacterium extorquens AM1 ${ }^{\mathrm{rif}}$. J Bacteriol 174, 4444-4449.

Morris, C. J., Biville, F., Turlin, E., Lee, E., Ellermann, K., Fan, W. H., Ramamoorthi, R., Springer, A. L. \& Lidstrom, M. E. (1994). Isolation, phenotypic characterization, and complementation analysis of mutants of Metbylobacterium extorquens AM1 unable to synthesize pyrroloquinoline quinone and sequences of $p q q D, p q q G$ and pqqC. J Bacteriol 176, 1746-1755.

Novak, P., Ray, P. H. \& Dev, I. K. (1986). Localisation and purification of two enzymes from Eschericbia coli capable of hydrolysing a signal peptide. $J$ Biol Chem 261, 420-427.

Nunn, D. N. \& Anthony, C. (1988). The nucleotide sequence and deduced amino acid sequence of the cytochrome $c_{\mathrm{L}}$ gene of Methylobacterium extorquens AM1 : a novel class of $c$-type cytochrome. Biochem J 256, 673-676.

Nunn, D. N. \& Lidstrom, M. E. (1986a). Isolation and complementation analysis of 10 methanol oxidation mutant classes and identification of the methanol dehydrogenase structural gene of Metbylobacterium sp. strain AM1. J Bacteriol 166, 581-590.

Nunn, D. N. \& Lidstrom, M. E. (1986b). Phenotypic characterisation of 10 methanol oxidation mutant classes of Metbylobacterium sp. strain AM1. J Bacteriol 166, 591-597.

Nunn, D. N., Day, D. J. \& Anthony, C. (1989). The second subunit of methanol dehydrogenase of Methylobacterium extorquens AM1. Biocbem J 260, 857-862.

O'Connor, M. L. \& Hanson, R. S. (1977). Enzyme regulation in Metbylobacterium organophilum. J Gen Microbiol 101, 327-332.

Oliver, D. B. (1993). SecA protein: autoregulated ATPase catalysing preprotein insertion and translocation across the Eschericbia coli membrane. Mol Microbiol 7, 159-165.

Oozeer, F., Page, M. D., Ferguson, S. J. \& Goodwin, P. M. (1993). Phenotypic characterization of $c$-type-cytochrome-deficient mutants of Metbylobacterium extorquens AM1 and identification of two chromosomal regions essential for the production of $c$-type cytochromes. J Gen Microbiol 139, 11-19.

Page, M. D. \& Ferguson, S. J. (1989). A bacterial $c$-type cytochrome can be translocated to the periplasm as an apo form; the biosynthesis of cytochrome $c d 1$ (nitrite reductase) from Paracoccus denitrificans. Mol Microbiol 3, 653-661.

Page, M. D. \& Ferguson, S. J. (1990). Apo-forms of cytochrome $c-550$ and cytochrome $c d 1$ are translocated to the periplasm of Paracoccus denitrificans in the absence of haem incorporation caused by either mutation or inhibition of haem synthesis. Mol Microbiol 4, 1181-1192.

Page, M. D. \& Ferguson, S. J. (1993). Mutants of Metbylobacterium extorquens and Paracoccus denitrificans deficient in $c$-type cytochrome biogenesis synthesise the methylamine-dehydrogenase polypeptides but cannot assemble the tryptophan-tryptophylquinone group. Eur J Biochem 218, 711-717.

Page, M. D. \& Ferguson, S. J. (1994). Differential reduction in soluble and membrane-bound $c$-type cytochrome contents in a Paracoccus denitrificans mutant partially deficient in 5-aminolevulinate synthase activity. J Bacteriol 176, 5919-5928.

Parkinson, J. S. (1993). Signal transduction schemes of bacteria. Cell 73, 857-871.

Poole, R. K., Gibson, F. \& Wu, G. H. (1994). The $c y d D$ gene product, component of a heterodimeric $\mathrm{ABC}$ transporter, is required for assembly of periplasmic cytochrome $c$ and of cytochrome $b d$ in Escherichia coli. FEMS Microbiol Lett 117, 217-224.

Pugsley, A. P. (1993). The complete general secretory pathway in Gram-negative bacteria. Microbiol Rev 57, 50-108.

Ramamoorthi, R. \& Lidstrom, M. E. (1995). Transcriptional analysis of $p q q D$ and study of the regulation of pyrroloquinoline quinone biosynthesis in Metbylobacterium extorquens AM1. J Bacteriol 177, 206-211.

Ramseier, T. M., Winteler, H. V. \& Hennecke, H. (1991). Discovery and sequence analysis of bacterial genes involved in the biogenesis of $c$-type cytochromes. J Biol Chem 266, 7793-7803.

Richardson, I. W. \& Anthony, C. (1992). Characterization of mutant forms of the quinoprotein methanol dehydrogenase lacking an essential calcium ion. Biochem $J$ 287, 709-715.

Ritz, D., Bott, M. \& Hennecke, H. (1993). Formation of several bacterial $c$-type cytochromes requires a novel membrane-anchored protein that faces the periplasm. Mol Microbiol 9, 729-740.

Roitsch, T. \& Stolp, H. (1986). Synthesis of dissimilatory enzymes of serine type methylotrophs under different growth conditions. Arcb Microbiol 144, 245-247.

Salmond, G. P. C. \& Reeves, P. J. (1993). Membrane traffic wardens and protein secretion in Gram negative bacteria. Trends Biochem Sci 18, 7-12.

Sambongi, Y. \& Ferguson, S. J. (1994). Specific thiol compounds complement deficiency in $c$-type cytochrome biogenesis in Escherichia coli carrying a mutation in a membrane-bound disulphide isomerase-like protein. FEBS Lett 353, 235-238.

van Spanning, R. J. M., Wansell, C. W., Deboer, T., Hazelaar, M. J., Anazawa, H., Harms, N., Oltmann, L. F. \& Stouthamer, A. H. (1991). Isolation and characterization of the $\operatorname{mox} J, \operatorname{mox} G, \operatorname{mox} I$, and moxR genes of Paracoccus denitrificans - inactivation of moxJ, moxG, and $\operatorname{mox} R$ and the resultant effect on methylotrophic growth. $J$ Bacteriol 173, 6948-6961.

van Spanning, R. J. M., Vanderpalen, C. J. N. M., Slotboom, D. J., Reijnders, W. N. M., Stouthamer, A. H. \& Duine, J. A. (1994). Expression of mau genes involved in methylamine metabolism in Paracoccus denitrificans is under control of a LysR-type transcriptional activator. Eur J Biochem 226, 201-210.

Stephens, R. L., Haygood, M. G. \& Lidstrom, M. E. (1988). Identification of putative methanol dehydrogenase (moxF) structural genes in methylotrophs and cloning of $\operatorname{mox} F$ genes from Metbylococcus capsulatus Bath and Metbylomonas albus BG8. J Bacteriol 170, 2063-2069.

Thonymeyer, L., Loferer, H., Ritz, D. \& Hennecke, H. (1994a). Bacterial genes and proteins involved in the biogenesis of $c$-type cytochromes and terminal oxidases. BBA-Bioenergetics 1187, 260-263.

Thonymeyer, L., Ritz, D. \& Hennecke, H. (1994b). Cytochrome $c$ biogenesis in bacteria - a possible pathway begins to emerge. Mol Microbiol 12, 1-9.

Ubbink, M., Vankleef, M. A. G., Kleinjan, D. J., Hoitink, C. W. G., Huitema, F., Beintema, J. J., Duine, J. A. \& Canters, G. W. (1991). Cloning, sequencing and expression studies of the genes encoding amicyanin and the beta-subunit of methylamine dehydrogenase from Thiobacillus versutus. Eur J Biochem 202, 1003-1012.

Vellieux, F. M. D., Huitema, F., Groendijk, H., Kalk, K. H., Frank, J., Jongejan, J. A., Duine, J. A., Petratos, K., Drenth, J. \& Hol, W. G. J. (1989). Structure of quinoprotein methylamine dehydrogenase at $2 \cdot 25 \AA$ resolution. EMBO J 8, 2171-2178. 
Waechterbrulla, D., Dispirito, A. A., Chistoserdova, L. V. \& Lidstrom, M. E. (1993). Methanol oxidation genes in the marine methanotroph Metbylomonas sp strain-a4. J Bacteriol 175, 3767-3775.

White, S., Boyd, G., Mathews, F. S., Xia, Z. X., Dai, W. W., Zhang, Y. F. \& Davidson, V. L. (1993). The active site structure of the calcium-containing quinoprotein methanol dehydrogenase. Biochemistry 32, 12955-12958.

Wickner, W., Driessen, A. J. M. \& Hartl, F.-U. (1991). The enzymology of protein translocation across the Escherichia coli plasma membrane. Annu Rev Biochem 60, 101-124.

Willison, J. C. \& John, P. (1979). Mutants of Paracoccus denitrificans deficient in $c$-type cytochromes. J Gen Microbiol 115, 443-450.
Wolin, S. L. (1994). From the elephant to E. coli: SRP-dependent protein targeting. Cell 77, 787-790.

Wulfing, C. \& Pluckthun, A. (1994). Protein folding in the periplasm of Escherichia coli. Mol Microbiol 12, 685-692.

Xia, Z. X., Dai, W. W., Xiong, J. P., Hao, Z. P., Davidson, V. L., White, S. \& Mathews, F. S. (1992). The 3-dimensional structures of methanol dehydrogenase from 2 methylotrophic bacteria at 2.6angstrom resolution. J Biol Chem 267, 22289-22297.

Xu, H. H., Viebahn, M. \& Hanson, R. S. (1993). Identification of methanol-regulated promoter sequences from the facultative methylotrophic bacterium Methylobacterium organophilum XX.J Gen Microbiol 139, 743-752. 